\title{
The psychical status and functional state of the central nervous system of high school leavers in the dynamics of the academic year
}

\author{
Lubov Gubareva ${ }^{1, *}$, Yulia Konygeva $^{1}$ and Larisa Chernyavskaya $^{2}$ \\ ${ }^{1}$ North-Caucasus Federal University, Stavropol 355017, Russia \\ ${ }^{2}$ Municipal budgetary educational institution secondary school No.2, Stavropol 355006, Russia
}

\begin{abstract}
The purpose of the study was to research the change in the psychical status and functional state of the central nervous system of high school leavers taking the Unified State Exam (USE) in the dynamics of the academic year. 85 high school leavers of the 11 th form were put under study. The functional state of the CNS was determined by the method of computer chronoreflexometry, psychical status - with the help of "the Methodology for Diagnosing Learning Motivation and Emotional Attitude to Learning in Middle and High School", "Spielberger's Methodology for Identifying Personal and Situational Anxiety", and "Determination of susceptibility to stress". It was found that the boys and girls of the 11th form had the maximum level of motivation for learning at the beginning of the school year. By the end of the school year, the girls' level of motivation for learning decreases while the achievement motivation and anxiety level increase significantly. The level of personal anxiety among girls is also considerably higher than among boys. At the beginning of the school year stress resistance among boys is higher than among girls. Preparation for the USE during the academic year cause significant changes in the functional state of the CNS, which are more pronounced in schoolgirls. The results of the study can be put into the basis for monitoring the state of psychosomatic health of high school leavers as well as be used as markers when performing psychocorrectional activities to restore an optimum functional CNS state and a psychoemotional status.
\end{abstract}

\section{Introduction}

At present a compulsory form of certification in Russia is the Unified State Exam (USE), the purpose of which is to improve the efficiency and quality of school education. It should be noted that in order to obtain a school certificate and enter a higher educational institution, the Unified exam is taken in a number of near and far foreign countries (Ukraine, Kazakhstan, Italy, Germany, Japan, USA, etc.). Abroad as well as in Russia, it is believed that academic performance is important as it strongly affects a person's life chances [1]. The relation between academic performance and life satisfaction has been shown [2].

The unified state exam causes a lot of controversy and doubts among teachers and parents,

\footnotetext{
*Corresponding author: 1-gubareva@mail.ru
} 
practical psychologists and school administrators because of the complexity of the USE procedure and its high stress potential [3]. In this regard, the problem of studying the high school leavers' psychophysiological peculiarities that enable to pass the Unified State Exam successfully remains very urgent.

The study urgency is also stipulated by the fact that it is school leavers who undergo more intense academic loading connected with the preparation and taking of the Unified State Exam, the choice of a further professional path.

For the last decades, there has been a growing interest in the study of schoolchildren perceptions of their well-being as an indicator of mental health [4]. At the same time, the level of anxiety is considered as an indicator of emotional well-being [5]. The results of a study by Suldo and Shaffer (2008) [6] showed that academically successful students had good mental health, while adolescents from the "vulnerable" group performed worse. However, in most cases, the psycho-emotional state of the subjects is assessed, while the physiological foundations that ensure the effective USE passing are obviously studied insufficiently.

The aim of the study was to research the change in the psychic status and functional state of the central nervous system (CNS) of high school leavers taking an USE in the dynamics of the academic year.

\section{Subject and Methods}

The study was conducted on the basis of the scientific educational laboratory (SEL) "Environmental Psychophysiology" of North Caucasus Federal University in accordance with the requirements of the Helsinki Declaration on Human Rights and Biomedical Ethic. In a natural experiment, with freewill consent, 85 school leavers without genetic pathology (43 boys and 42 girls) from the $11^{\text {th }}$ form of secondary school №2 in Stavropol were put under study. The average age of boys was $16.9 \pm 0.06$ years old, girls $-16.8 \pm 0.07$ years old $(p>0.5)$. The functional state of the central nervous system was determined by the method of computer chronoreflexometry according to the indicators of complex visual-motor reaction (SVMR) to color stimuli with a computer device "Psychophysiologist UPFT-1/30" (manufactured and verified by the of Limited Company "Medikom", Taganrog).

Psychological testing was carried out with "the Methodology for diagnosing motivation for learning and emotional attitude to learning in middle and high school", "Spielberger's Methodology for Identifying Personal and Situational Anxiety", and "Determination of susceptibility to stress" [7].

The survey was carried out taking into account the circadian, weekly biorhythms. The research results were subjected to variational and statistical computer processing with using a statistical data analysis package in Microsoft Excel-2006.

\section{Results}

As mentioned above, an important role in the effectiveness of learning is assigned to motivation for learning and the emotional state of students. Based on this, we used a methodology for determining indicators of motivation for learning and emotional attitude to learning, which allows to identify not only the motivation for academic achievement, but also the level of cognitive activity, the level of anxiety and anger as well as five levels of motivation for learning. According to the results of the study (Table 1), in terms of achievement motivation and the integral level of motivation to learn (LML), there were no significant sex differences, that indicates the high significance of these indicators in the effectiveness of training. At the beginning of their final school year, both boys and girls of the $11^{\text {th }}$ form had the maximum LML indicating productive motivation and a positive attitude 
towards learning $(2.38 \pm 0.21$ points and $2.81 \pm 0.15$ points respectively, $\mathrm{p}>0.05)$. By the end of the school year, the girls' LML decreases to $3.00 \pm 0.26$ pts, which corresponds to the average level with a slightly reduced cognitive motivation. And this happens against the background of a significant increase in achievement motivation and the level of anxiety (Table 1), which can be regarded as a decrease in the body's reserve capabilities. The emotional status of the boys is more stable and does not change significantly during the school year, judging by the indicators of anxiety and anger. The level of anxiety among girls is significantly higher than among boys both at the beginning and at the end of the school year (Table 1).

Table 1. Indicators of achievement motivation $(\mathrm{M} \pm \mathrm{m})$ for high school leavers, taking an USE, at the beginning and at the end of the academic year.

\begin{tabular}{|c|c|c|c|c|c|c|}
\hline \multirow[t]{2}{*}{ Indicators } & \multicolumn{2}{|c|}{$\begin{array}{c}\text { Beginning of the } \\
\text { academic year }(n=61)\end{array}$} & \multirow[t]{2}{*}{$\mathbf{P}_{2}$} & \multicolumn{2}{|c|}{$\begin{array}{c}\text { The end of the academic } \\
\text { year }(n=24)\end{array}$} & \multirow[t]{2}{*}{$\mathbf{P}_{2}$} \\
\hline & boys & girls & & boys & girls & \\
\hline $\begin{array}{l}\text { 1. Anxiety. } \\
\text { points }\end{array}$ & $17.0 \pm 0.9$ & $20.0 \pm 1.0$ & $<0.05$ & $17.2 \pm 0.8$ & $24.7 \pm 0.9$ & $<0.01$ \\
\hline $\mathrm{P}_{1}$ & & & & $>0.5$ & $<0.05$ & \\
\hline $\begin{array}{l}\text { 2. Cognitive } \\
\text { activity. points }\end{array}$ & $31.0 \pm 1.1$ & $30.0 \pm 0.9$ & $>0.5$ & $29.8 \pm 1.1$ & $30.8 \pm 1.0$ & $>0.5$ \\
\hline$P_{1}$ & & & & $>0.5$ & $>0.5$ & \\
\hline $\begin{array}{l}\text { 1. Ang } \\
\text { er. points }\end{array}$ & $14.0 \pm 1.1$ & $16.0 \pm 0.9$ & $>0.05$ & $15.3 \pm 1.2$ & $15.2 \pm 1.1$ & $>0.5$ \\
\hline $\mathrm{P}_{1}$ & & & & $>0.5$ & $>0.5$ & \\
\hline $\begin{array}{l}4 . \\
\text { Achievement } \\
\text { motivation. } \\
\text { points }\end{array}$ & $30.8 \pm 0.8$ & $28.5 \pm 0.9$ & $>0.05$ & $28.9 \pm 1.1$ & $31.2 \pm 1.2$ & $>0.05$ \\
\hline $\mathrm{P}_{1}$ & & & & $>0.05$ & $<0.05$ & \\
\hline $\begin{array}{l}\text { 5. Level of } \\
\text { motivation to } \\
\text { learn. points }\end{array}$ & $2.38 \pm 0.21$ & $2.81 \pm 0.15$ & $>0.05$ & $2.58 \pm 0.21$ & $3.00 \pm 0.26$ & $>0.05$ \\
\hline $\mathrm{P}_{1}$ & & & & $>0.5$ & $>0.5$ & \\
\hline
\end{tabular}

Note: P1 - reliability of differences compared to the beginning of the school year;

P2 - reliability of sex differences; in parentheses the number of examined.

The analysis of the results of testing the level of personality (basal) anxiety of the 11th form pupils (Table 2) showed that at the beginning of the school year girls have a higher level of personality anxiety than boys $(\mathrm{p}<0.05-0.01)$. In the course of training, the level of boys' personality anxiety remains relatively constant, as for the girls' one it increases significantly - from $20.0 \pm 1.1$ pts. up to $24.7 \pm 0.9$ pts. $(\mathrm{p}<0.05)$. In terms of the level of situational (reactive) anxiety at the beginning of the school year, no significant sex differences were revealed. At the end of the academic year, the level of school leaving girls' situational anxiety tends to increase, and the boys' one - to decrease (Table 2), which can be regarded as an indicator of a more stable functional state of the central nervous system of boys compared to girls of this age group.

Table 2. Indicators of personality and situational anxiety $(\mathrm{M} \pm \mathrm{m})$ for high school leavers, taking an USE, at the beginning and at the end of the academic year.

\begin{tabular}{|l|c|c|c|c|c|c|}
\hline \multirow{2}{*}{ Indicators } & \multicolumn{2}{|c|}{$\begin{array}{c}\text { Beginning of the } \\
\text { academic year }(\mathbf{n}=\mathbf{6 1})\end{array}$} & \multirow{2}{*}{$\mathbf{P}_{\mathbf{2}}$} & \multicolumn{2}{c|}{$\begin{array}{c}\text { The end of the } \\
\text { academic year }(\mathbf{n}=\mathbf{2 4})\end{array}$} & \multirow{2}{*}{$\mathbf{P}_{\mathbf{2}}$} \\
\cline { 2 - 3 } \cline { 5 - 6 } & boys & girls & & boys & girls & \\
\hline $\begin{array}{l}\text { 1. Personality } \\
\text { anxiety. points }\end{array}$ & $17.0 \pm 0.9$ & $20.0 \pm 1.1$ & $<0.05$ & $17.2 \pm 0.8$ & $24.7 \pm 0.9$ & $<0.01$ \\
\hline
\end{tabular}




\begin{tabular}{|l|c|c|c|c|c|c|}
\hline $\mathrm{P}_{1}$ & & & & $>0.5$ & $<0.05$ & \\
\hline $\begin{array}{l}2 . \quad \text { Situational } \\
\text { anxiety. points }\end{array}$ & $31.0 \pm 1.1$ & $30.0 \pm 1.0$ & $>0.5$ & $29.8 \pm 1.1$ & $30.8 \pm 1.0$ & $>0.5$ \\
\hline $\mathrm{P}_{1}$ & & & & $>0.5$ & $>0.5$ & \\
\hline
\end{tabular}

Note: P1 - reliability of differences compared to the beginning of the school year;

P2 - reliability of sex differences; in parentheses the number of examined.

The results of stress resistance testing of high school leavers showed that at the beginning of the academic year, stress resistance of boys is higher than the one of girls (Fig. 1): they are less irritable and are able to control these qualities. By the end of the school year, 17year-old boys' resistance to stress did not change significantly, while the girls showed an inversion of stress resistance indicators.

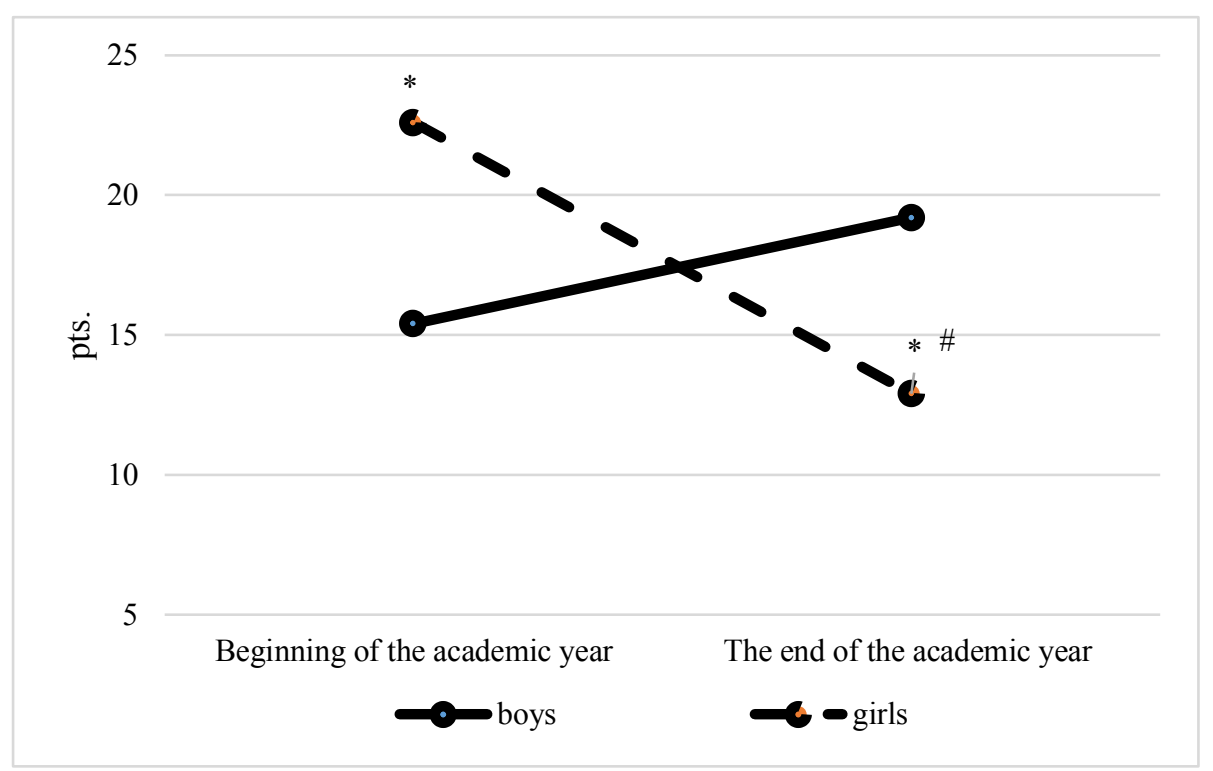

Fig. 1. Dynamics of stress resistance for high school leavers during the academic year.

Note: $*$ - reliability of differences compared to the beginning of the school year;

\# - reliability of sex differences.

One of the most important indicators of mental health and the level of adaptation to environmental factors is the functional state of CNS. The central nervous system reacts to the influence of external factors as a specialized control system that coordinates the adaptation process of the whole organism. The objective criterion of the functional state of CNS is the time and accuracy of the reaction, which characterize the rate of CNS inhibition and excitation, the ability to differentiate inhibition and the severity of excitatory or inhibitory processes during sensorimotor reactions [8]. These requirements are met by a complex visual-motor reaction (CVMR), in which two color signals are presented - red and green, and the testee must respond to each of them with a certain predetermined movement.

The CNS functional state at the beginning of the school year was characterized by the absence of pronounced sex differences between the boys and girls of the $11^{\text {th }}$ form in terms of the main functional indicators of CNS: the number of missed and pre-emptive stimuli, the number of errors in differentiation, the time of CVMR, the mode (Mo) and amplitude of the mode (AMo), the minimum reaction time, that corresponds to the ontogenesis period (Table 3 ). At the same time, at the beginning of the academic year, the girls, who were leaving school, differed from the boys in significantly lower indicators of the standard deviation of the reaction time and maximum time of CVMR (Table 3), which indicates a higher stability 
of the CNS functioning and is consistent with data on the advanced development of the nervous system of girls compared to boys [9].

Table 3. Indicators of complex visual-motor reaction (CVMR) (M $\pm m$ ) for high school leavers, taking an USE, at the beginning and at the end of the academic year.

\begin{tabular}{|c|c|c|c|c|c|c|}
\hline \multirow{2}{*}{$\begin{array}{l}\text { Indicator } \\
\qquad s\end{array}$} & \multicolumn{2}{|c|}{$\begin{array}{c}\text { Beginning of the } \\
\text { academic year }(n=61)\end{array}$} & \multirow[t]{2}{*}{$\mathbf{P}_{2}$} & \multicolumn{2}{|c|}{$\begin{array}{c}\text { The end of the academic } \\
\text { year }(n=24)\end{array}$} & \multirow[t]{2}{*}{$\mathbf{P}_{2}$} \\
\hline & boys & girls & & boys & girls & \\
\hline $\begin{array}{l}1 . \\
\text { Integral } \\
\text { indicator } \\
\text { of the } \\
\text { reliability } \\
\text {.c. u. }\end{array}$ & $58.8 \pm 3.3$ & $62.7 \pm 1.3$ & $>0.1$ & $44.0 \pm 4.0$ & $45.0 \pm 3.9$ & $>0.5$ \\
\hline $\mathrm{P}_{1}$ & & & & $<0.05$ & $<0.01$ & \\
\hline $\begin{array}{l}2 . \text { Level } \\
\text { of } \\
\text { sensorimo } \\
\text { tor } \\
\text { reactions }\end{array}$ & $\begin{array}{c}3.33 \pm 0.3 \\
1\end{array}$ & $3.67 \pm 0.37$ & $>0.5$ & $\begin{array}{c}2.60 \pm 0.2 \\
3\end{array}$ & $2.20 \pm 0.34$ & $>0.1$ \\
\hline $\mathrm{P}_{1}$ & & & & $>0.05$ & $<0.05$ & \\
\hline $\begin{array}{l}3 . \\
\text { Number } \\
\text { of missed } \\
\text { stimuli }\end{array}$ & $\begin{array}{c}0.60 \pm 0.4 \\
0\end{array}$ & $0.00 \pm 0.00$ & $>0.05$ & $\begin{array}{c}0.10 \pm 0.0 \\
6\end{array}$ & $0.50 \pm 0.25$ & $>0.05$ \\
\hline $\mathrm{P}_{1}$ & & & & $>0.1$ & $<0.05$ & \\
\hline $\begin{array}{l}4 . \\
\text { Number } \\
\text { of } \\
\text { pre- } \\
\text { emptive } \\
\text { stimuli }\end{array}$ & $\begin{array}{c}0.90 \pm 0.4 \\
1\end{array}$ & $0.44 \pm 0.20$ & $>0.1$ & $\begin{array}{c}0.50 \pm 0.1 \\
5\end{array}$ & $0.67 \pm 0.15$ & $>0.5$ \\
\hline $\mathrm{P}_{1}$ & & & & $>0.1$ & $>0.5$ & \\
\hline $\begin{array}{l}5 . \\
\text { Number } \\
\text { of errors } \\
\text { in } \\
\text { differenti } \\
\text { ation }\end{array}$ & $\begin{array}{c}1.00 \pm 0.2 \\
3\end{array}$ & $0.67 \pm 0.31$ & $>0.1$ & $\begin{array}{c}1.20 \pm 0.1 \\
9\end{array}$ & $1.20 \pm 0.22$ & $>0.5$ \\
\hline $\mathrm{P}_{1}$ & & & & $>0.5$ & $>0.05$ & \\
\hline $\begin{array}{ll}6 . & \Sigma \\
\text { errors } & \\
\text { number } & \end{array}$ & $\begin{array}{c}2.00 \pm 0.4 \\
6\end{array}$ & $1.11 \pm 0.40$ & $>0.05$ & $\begin{array}{c}1.80 \pm 0.2 \\
6\end{array}$ & $2.60 \pm 0.50$ & $>0.05$ \\
\hline $\mathrm{P}_{1}$ & & & & $>0.5$ & $<0.05$ & \\
\hline $\begin{array}{l}7 . \text { Level } \\
\text { of } \\
\text { faultlessn } \\
\text { ess of } \\
\text { CVMR }\end{array}$ & $\begin{array}{c}3.33 \pm 0.3 \\
1\end{array}$ & $4.11 \pm 0.35$ & $>0.05$ & $\begin{array}{c}3.20 \pm 0.2 \\
6\end{array}$ & $2.40 \pm 0.44$ & $>0.05$ \\
\hline $\mathrm{P}_{1}$ & & & & $>0.5$ & $<0.05$ & \\
\hline $\begin{array}{l}8 . \\
\text { time of } \\
\text { CVMR. } \\
\text { Ms }\end{array}$ & $\begin{array}{c}424.2 \pm 2 \\
1.0\end{array}$ & $413.1 \pm 17.4$ & $>0.5$ & $\begin{array}{c}514.7 \pm 2 \\
5.4\end{array}$ & $515.6 \pm 23.1$ & $>0.5$ \\
\hline $\mathrm{P}_{1}$ & & & & $<0.05$ & $<0.05$ & \\
\hline 9. $\quad$ Level & $4.0 \pm 0.20$ & $4.0 \pm 0.23$ & $>0.5$ & $2.80 \pm 0.2$ & $2.50 \pm 0.45$ & $>0.05$ \\
\hline
\end{tabular}




\begin{tabular}{|c|c|c|c|c|c|c|}
\hline $\begin{array}{l}\text { of speed } \\
\text { of CVMR }\end{array}$ & & & & 6 & & \\
\hline $\mathrm{P}_{1}$ & & & & $<0.01$ & $<0.05$ & \\
\hline $\begin{array}{l}10 . \\
\text { Standard } \\
\text { deviation } \\
\text { of the } \\
\text { reaction } \\
\text { time. Ms }\end{array}$ & $\begin{array}{c}147.1 \pm 1 \\
9.0\end{array}$ & $88.9 \pm 7.4$ & $<0.05$ & $\begin{array}{c}149.2 \pm 1 \\
1.0\end{array}$ & $215.0 \pm 17.0$ & $<0.05$ \\
\hline $\mathrm{P}_{1}$ & & & & $>0.5$ & $<0.001$ & \\
\hline $\begin{array}{l}\text { 11. Level } \\
\text { of } \\
\text { stability } \\
\text { of CVMR }\end{array}$ & $\begin{array}{c}3.38 \pm 0.2 \\
3\end{array}$ & $3.56 \pm 0.23$ & $>0.5$ & $\begin{array}{c}2.20 \pm 0.2 \\
2\end{array}$ & $1.88 \pm 0.22$ & $>0.1$ \\
\hline $\mathrm{P}_{1}$ & & & & $<0.05$ & $<0.001$ & \\
\hline $\begin{array}{l}\text { 12. Mo of } \\
\text { the } \\
\text { reaction } \\
\text { time. Ms }\end{array}$ & $\begin{array}{c}404.0 \pm 2 \\
6.9\end{array}$ & $388.9 \pm 16.2$ & $>0.5$ & $\begin{array}{c}261.4 \pm 2 \\
0.1\end{array}$ & $148.0 \pm 17.3$ & $<0.01$ \\
\hline $\mathrm{P}_{1}$ & & & & $<0.01$ & $<0.001$ & \\
\hline $\begin{array}{l}\text { 13. AMo } \\
\text { of the } \\
\text { reaction } \\
\text { time. } \%\end{array}$ & $24.4 \pm 1.5$ & $25.9 \pm 1.6$ & $>0.5$ & $24.0 \pm 1.2$ & $18.6 \pm 1.1$ & $<0.05$ \\
\hline $\mathrm{P}_{1}$ & & & & $>0.5$ & $<0.01$ & \\
\hline $\begin{array}{l}14 . \\
\text { Minimal } \\
\text { reaction } \\
\text { time. MS }\end{array}$ & $\begin{array}{c}266.2 \pm 6 . \\
1\end{array}$ & $269.1 \pm 9.3$ & $>0.5$ & $\begin{array}{c}295.8 \pm 1 \\
1.7\end{array}$ & $273.4 \pm 9.5$ & $>0.05$ \\
\hline $\mathrm{P}_{1}$ & & & & $<0.05$ & $>0.5$ & \\
\hline $\begin{array}{l}15 . \\
\text { Maximal } \\
\text { reaction } \\
\text { time. Ms }\end{array}$ & $\begin{array}{c}901.5 \pm 1 \\
11.5\end{array}$ & $621.5 \pm 36.2$ & $<0.05$ & $\begin{array}{c}942.4 \pm 5 \\
4.3\end{array}$ & $955.5 \pm 42.3$ & $>0.5$ \\
\hline $\mathrm{P}_{1}$ & & & & $>0.5$ & $<0.01$ & \\
\hline
\end{tabular}

Note: P1 - reliability of differences compared to the beginning of the school year; P2 reliability of sex differences; in parentheses the number of examined; Mo - mode; AMo mode amplitude, c. u. - conventional unit.

Teaching and preparation for the Unified State Exam during the academic year caused significant changes in the functional state of the central nervous system in both boys and girls in graduating classes. Thus, by the end of the academic year, an increase in the time of CVMR was recorded for boys from $424.2 \pm 21.0 \mathrm{~ms}$ to $514.7 \pm 25.4 \mathrm{~ms}(\mathrm{p}<0.05)$, for girls from $413.1 \pm 17.4 \mathrm{~ms}$ to $515.6 \pm 23.1 \mathrm{~ms}(\mathrm{p}<0.05)$, which led to a decrease in the rate of CVMR and the level of speed of CNS performance for the students of the 11th form (Table 3, Fig. 2). 


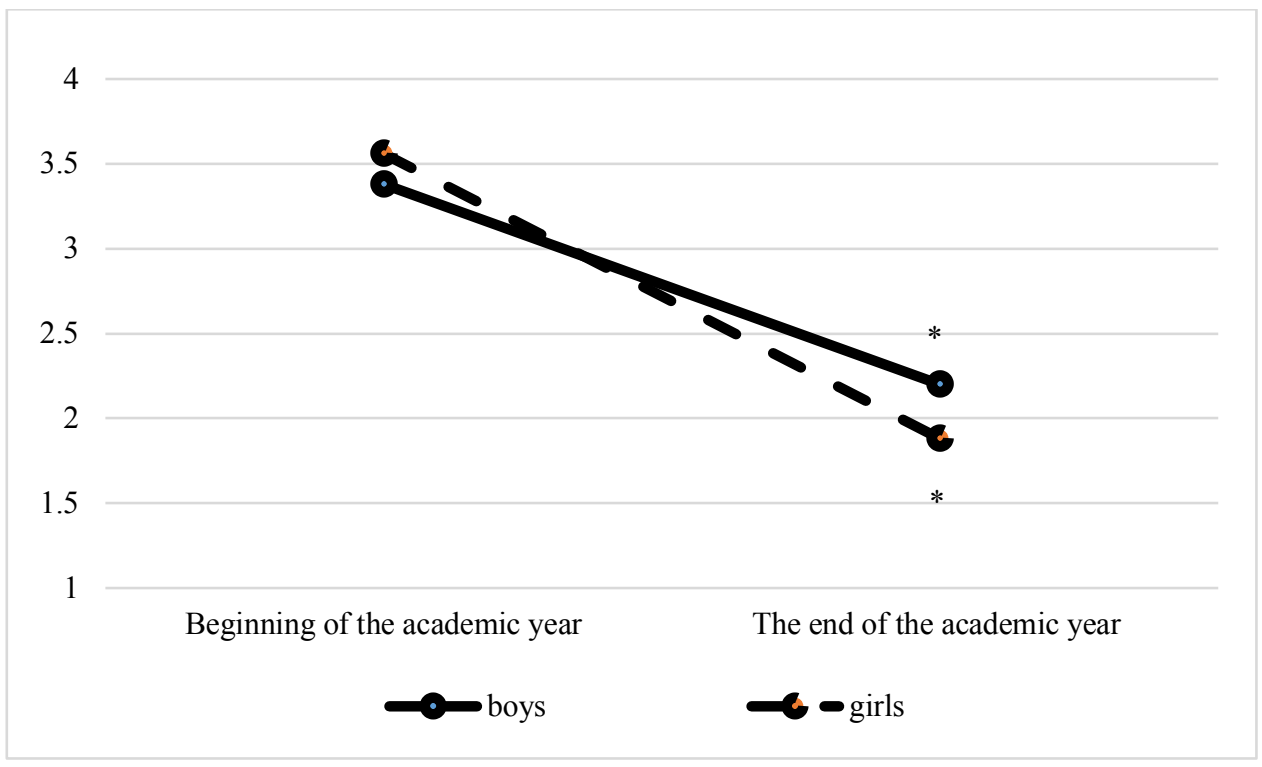

Fig. 2. Dynamics of the stability of CVMR for high school leavers during the academic year.

Note: * - reliability of differences compared to the beginning of the school year.

At the same time, by the end of the school year, the girls of the $11^{\text {th }}$ form showed a decrease in the accuracy of CVMR performance, that was proved by a significant increase in the number of missed stimuli $(\mathrm{p}<0.05)$ and the total number of errors $(\mathrm{p}<0.05)$ in comparison with the beginning of the academic year and, as a consequence, a decrease in the level of faultlessness of complex sensorimotor reactions $(p<0.05)$ (Table 3, Fig. 3).

Changes in the objective indicators of the functional state of CNS led to a decrease in the level of sensorimotor reactions by 1.3 times for boys $(p<0.05)$ and 1.7 times for girls $(p$ $<0.05$ ), as well as in an integral indicator of the reliability of the nervous system functioning by 1.3 times for boys $(p<0.05)$ and 1.4 times for girls $(p<0.01)$ (Table 3$)$.

In general, according to the majority of indicators, the girls in their final school year of studies had more pronounced negative changes. It should be noted that at the end of the academic year, the $11^{\text {th }}$-form girls showed a higher level of CNS adaptive capabilities than boys, in indicators of the standard deviation of the reaction time $(215.0 \pm 17.0 \mathrm{~ms}$ and 149.2 $\pm 11.0 \mathrm{~ms}$, respectively, $\mathrm{p}<0.05)$.

\section{Discussion}

The objectives of the USE are forming a system of unbiased assessment of the training level of leavers of secondary schools, gymnasiums, lyceums; increasing the availability of higher and vocational education; provision of conditions for state control and quality management of general education. At the same time, according to teachers and psychologists, schools leavers and their parents, the complexity of the USE procedure determines its high stress potential. Gilman and Huebner [10] found that life satisfaction was positively connected with average academic marks of the adolescent and their school attitudes, and was negatively correlated with psychopathological problems such as depression or social stress. In this regard, the problem of studying the high school leavers' psychophysiological characteristics contributing to the successful passing of the exam remains very topical. According to E.N. Filippova, I.I. Kopylova [11], "personal peculiarities, the level of intellectual development, temperamental characteristics, emotional and volitional qualities, motivation make a 
significant contribution to the success of adaptation of the studing youth". Personal qualities include genetically determined levels of personality and situational anxiety. The process of taking the exam itself causes a pronounced psychoemotional stress, therefore, according to R.E. Prokhorov [12], personality and situational anxiety "are the factors that affect the success of the of exam taking". According to our earlier data, at the beginning of the school year the level of personality anxiety of "girls tends to increase throughout the entire period of high school, while that one of boys increases only in the $10^{\text {th }}$ form and decreases by the beginning of the $11^{\text {th }}$ form" [13]. In the present study, in the $11^{\text {th }}$ form, we established a higher level of girls' personality anxiety compared to boys' one not only at the beginning, but also at the end of the academic year, that indicates a higher level of psychoemotional tension of female school leavers.

Activity motivation, including educational motivation, plays a significant role in increasing the effectiveness of learning [14]. The data obtained by us also indicate the high importance of achievement motivation in learning efficiency. School leavers demonstrated the maximum level of motivation for learning (LML), indicating productive motivation as well as a positive attitude towards learning at the beginning of the academic year. By the end of the school year the girls' LML decreases. Earlier, we showed that "indicators of motivation for achievement show a pronounced relationship with the level of stability of the functional state of the CNS, noticeable - with the indicators of the standard deviation of the time CVMR, reflecting the adaptive capabilities of CNS, and indicators of the level of error-free reactions, the number of errors per differentiation. Indicators of anger closely correlate with the number of anticipatory stimuli and the level of infallibility, expressively - with the level of sensorimotor reactions, noticeably with the indicators of the speed of CVMR reactions" [13]. In the present study, it was found that training and preparation for the USE during the academic year caused significant changes in the functional state of CNS of both boys and girls leaving school: by the end of the academic year there was an increase in the time of CVMR, which led to a decrease in the CVMR speed and the level of CNS speed of the $11^{\text {th }}$ form students. At the same time, by the end of the school year, the accuracy of CVMR performance and the level of faultlessness of CVMR of the $11^{\text {th }}$-form girls decreased. Changes in the objective indicators of the functional state of CNS led to a decrease in the level of sensorimotor reactions and an integral indicator of the reliability of the functioning of the nervous system, which were more pronounced for the girls.

Summing up, one should pay attention to the fact that one of the main reasons for psychoemotional stress and the risk of adaptation diseases of secondary school leavers is the incompleteness of the processes of functional maturation of CNS of 17-year-old students [9]. Psychosocial risk factors can also make a significant contribution [15].

Timely assessment and monitoring of the functional state of CNS and indicators of achievement motivation, emotional attitude to learning, basal and reactive anxiety, the level of stress resistance during the preparation for the USE will allow to identify the degree of violations and to do the psycho-correctional work in good time.

The results of the study can be put into the basis for monitoring the state of psychosomatic health of school leaving students, as well as be used as regional standards when performing psychocorrectional activities to restore and maintain the optimum functional state of CNS and psychoemotional status.

\section{Conclusions}

1. It was found that the maximum level of motivation for learning, indicating productive motivation and a positive attitude to learning for boys and girls of the $11^{\text {th }}$ form was identified at the beginning of the school year. By the end of the academic year, the girls' LML decreases against the background of a significant increase in achievement motivation and the level of 
anxiety. The emotional status of $11^{\text {th }}$-form boys is more stable and does not change significantly during the school year, judging by the indicators of anxiety and anger.

2. The level of personality anxiety of the girls is significantly higher than that one of the boys both at the beginning and at the end of the school year. Stress resistance at the beginning of the academic year for the boys is higher than for the girls; by the end of the school year, stress resistance of the boys did not change significantly, while the girls showed an inversion of stress resistance indicators that is the evidence of a real assessment of events.

3. Teaching and preparation for the Unified State Exam during the academic year cause significant changes in the functional state of CNS of both school leaving boys and girls, namely: an increase of time and a decrease of the rate of CVMR and the level of speed of the central nervous system; a decrease of the level of sensorimotor reactions and of integral indicator of the reliability of the functioning of the central nervous system. In addition, by the end of the academic year, the accuracy of CVMR performance and, as a consequence, the girls' level of faultlessness of complex sensorimotor reactions decreased. At the same time, the $11^{\text {th }}$-form girls showed a higher level of adaptive capabilities of CNS than boys, judging by the indices of the standard deviation of the reaction time. In general, according to the majority of indicators, the girls in their final year of studies showed more pronounced negative changes.

4. The results of the study give grounds to recommend, for monitoring by doctors, teachers, practical psychologists, parents, rather informative and non-invasive markers of the organism adaptation to modern teaching loadings: anxiety, cognitive activity, anger, achievement motivation and motivation for learning; the level of personality and situational anxiety, indicators of stress resistance and complex visual-motor reaction (time and speed of CVMR, the number of missed and pre-emptive stimuli, the number of errors for differentiation, the standard deviation of the reaction time, the level of sensorimotor reactions and an integral indicator of the reliability of the CNS functioning).

\section{References}

1. R. Steinmayr, L. Wirthwein, C. Schöne, Learning and Individual Differences 32, 140147 (2014) doi: 10.1016 / j. lindif.2014.01.001

2. J. Crede, L. Wirthwein, N. McElvany, R. Steinmayr, Frontiers in Psychology 6(52) (2015) doi: 10.3389/fpsyg.2015.0052

3. S.N. Kostromina, A.E. Pisarev Statistics and Economics 3(14), 80-91 (2017) doi: 10.21686/2500-3925-2017-3-80-91

4. J. Bradshaw, P. Hoelscher, D. Richardson, Soc Indic Res 80, 133-177 (2007) doi: 10.1007/s11205-006-9024-z

5. F. Rüppel, L. Sebastian, U. Walter, J. Public Health 23, 15-24 (2015) doi: 10.1007/s10389-015-0654-y

6. S.M. Suldo, E.J. Shaffer-Hudkins, School Psychology Review 1(37), 52-68 (2008) doi: 10.1080/02796015.2008.12087908

7. R.V. Kupriyanov, Yu.M. Kuzmina, Psychodiagnostics of stress (Kazan National Research University of Technology, Kazan, 2012)

8. L.I. Gubareva, Ecological stress. Monograph (Lan, St. Petersburg, 2001)

9. T.A. Tsekhmistrenko, N.A. Chernykh, I.K. Shekhovtsev, Human Physiology 1(36), 3140 (2010)

10. R. Gilman, E.S. Huebner, J. Adolesc. 35, 311-319 (2006) doi: 10.1007/s10964-006

11. E.N. Filippova, I.I. Kopylova, Social adaptation of students at the university. In: 
International scientific student conference "Scientific potential of students - the future of Russia" (SKSTU, Stavropol, 2010)

12. R.E. Prokhorov, Psychological characteristics of secondary school graduates in preparation for the exam (Moscow, 2012)

13. L.I. Gubareva, Y.G. Konygeva, Psychophysiology News 4, 51-61 (2019)

14. R. Steinmayr, B. Spinath, Learning and Individual Differences 19, 80-90 (2009) doi: 10.1016/j.lindif.2008.05.004

15. N. Wille, S. Bettge, U. Ravens-Sieberer et al., European Child \& Adolescent Psychiatry 17(1), 133-147 (2008) doi: 10.1007/s00787-008-1015-y 